\title{
sciendo
}

DOI: 10.2478/orga-2019-0015

\section{Job Satisfaction and Citizenship Behavior: A Mediating Effect of Organizational Commitment}

\author{
A.K.M. Tafzal HAQUE ${ }^{1}$, Md. Aftab UDDIN ${ }^{2}$, Rubina EASMIN ${ }^{3}$ and \\ Shanewaz Mahmood SOHEL ${ }^{2}$ \\ ${ }^{1}$ University of Chittagong, Department of Management, Chattogram, Bangladesh 4331 \\ ${ }^{2}$ University of Chittagong, Department of Human Resource Management, Chattogram, Bangladesh 4331, mdaft- \\ abuddin@cu.ac.bd (Corresponding author) \\ ${ }^{3}$ East Delta University, School of Business, Chattogram, Bangladesh 4209
}

\begin{abstract}
Background and Purpose: Recently, job satisfaction has become a center of attention among academics, behavioral scientists, and business practitioners. Drawing on the tenet of the social exchange theory (SET) perspective and extending the conceptualization of the same, the present study aims at investigating the relationships among job satisfaction, organizational commitment, and citizenship behavior and mediation mechanism to unearth the effect of job satisfaction and organizational commitment on citizenship behavior.

Design/Methodology/Approach: Building on the positivist paradigm, we used quantitative research methodology following deductive reasoning approach. Henceforth, we have collected 210 replies from employees who have been serving Ready-made garments (RMG) sector that accounts for the highest export earning industry (84\% of the total export earning) in Bangladesh. We purposively selected Chittagong Export Processing Zone, the largest export processing zone in Bangladesh, for collecting our required data. Data were analyzed using the descriptive statistics, bivariate correlation, and structural equation model (SEM) using Smart PLS 2, a second-generation regression analysis, and SPSS 20.

Results: The structural model estimates that all the direct influences are significant excepting the impact of job satisfaction on citizenship behavior. Besides, the full mediation effect of organizational commitment was found in the relationships between job satisfaction and citizenship behavior.

Conclusion: The main implication is suggesting all corporate executives for creating an environment which will make employees very committed to letting them think out of the box beyond their required formal task requirement. In addition to a longitudinal study, further research on the moderating effect of demographic factors on the above variable is attested.
\end{abstract}

Keywords: Citizenship Behavior, Job Satisfaction, Organizational Commitment, RMG

\section{Introduction}

As a part of the broader strand of organizational psychology research, job satisfaction has become a center of focus among academics across discipline (Davia \& Legazpe, 2018). The employee seems to be a critical asset, and therefore, a satisfied employee turns out to be imperative and a vital predictor of a competitive firm (Ćulibrk, Delić, Mitrović, \& Ćulibrk, 2018). Henceforth, the study on antecedents stimulating job satisfaction at the workplace is more than essentials; however, the consequences of a satisfied employee are not adequately explored (Yousef,

Received: December 12, 2018; revised: August 23, 2019; accepted: August 24, 2019 
2017). Recently, employees pro-organizational activities are deemed to be virtually prerequisites for organizational surveillance, which is mostly because of the employees' job satisfaction (Uddin, Rahman, \& Howladar, 2014; Yen \& Teng, 2013) and inseparable emotional commitment (Uddin, Mahmood, \& Fan, 2019). In this age of acute perfection, a strategic manager wants their employees to work not only within their boundary but also proactively out of their boxes (citizenship behavior) for up-bringing the organization through a cutting-edge advantage. Working beyond required duties brings devastating effect on an organization (Robinson \& Bennett, 1995) and working proactively for bringing organizational competitiveness to the organization (Yen \& Teng, 2013).

An organization needs positively deviant employees who contribute to the wellbeing of the organism. In this regard, it is the organizational imperative to develop supportive working environments for building a very engaged (committed) and well-performing teams. Job satisfaction, a positive emotional state about the job, is an antecedent of citizenship behavior and commitment (Lambert, Qureshi, Frank, Klahm, \& Smith, 2018; Uddin et al., 2019). It is the positive evaluation of different aspects of a job by the employee (Mihaela, 2014; Yılmaz, Çelebi, \& Çakmak, 2014). Studies reported that a satisfied employee tends to be committed towards the organization (Lambert et al., 2018), which leads to their engagement in the citizenship behavior (Ćulibrk et al., 2018).

Employees' job satisfaction in the Ready-Made Garment (RMG) industry seems to be a critical antecedent for building up the organizational commitment, and citizenship behavior (Belwalkar, Vohra, \& Pandey, 2018). Job satisfaction in RMG is deemed to be very vital as the prodigious growth in the RMG industry of Bangladesh has been turned it into the second-largest exporting country in the world after China (Alam, Azim, \& Alias, 2017; Muhammad, 2015; Wadud, Huda, \& Ahmed, 2014). Notably, RMG alone earns approximately more than 84 percent of the total export (Islam, 2017; Shadat, Rahman, Rahman, \& Hawlader, 2016) and employs more than 4 million employees (Ahmed, Hasanuzzaman, Chowdhury, Shaikh, \& Munir, 2018; Bakht \& Hossain, 2017; Rahman \& Siddiqui, 2015; Wadud \& Huda, 2017) along with nearly \$30b export earning in FY18, from this sector (WTO, 2018).

Globally, numerous studies were documented conceiving of job satisfaction as an outcome variable of many antecedents (Lambert et al., 2018; Liu \& Lo, 2018; Manish, Hemang, Ashish, \& Sandeep, 2018; Smith, 2018; Stoermer, Haslberger, Froese, \& Kraeh, 2018). Surprisingly, the influence of job satisfaction as a predictor variable of citizenship behavior is not adequately examined (Nguni, Sleegers, \& Denessen, 2007). In an Indonesian study by Claudia (2018) attested on the essence of job satisfaction that investigates how job satisfaction turns employees commitment to citizenship behavior through their spiral effect. Since employees' citizenship behavior benefits or- ganization's well-being through the facilitation of shared benefits and pro-organizational tasks role, following the tenet of the social exchange theory (SET), i.e., Blau (1964), a dissatisfied employee do petite pro-organizational and cognitive mode or evaluation of job satisfaction influences the frequency of citizenship behaviors (Williams \& Anderson, 1991). Whereas Claudia (2018) reported that job satisfaction navigates commitment toward citizenship behavior, Ababneh and Hackett (2019) unlikely posited that both job satisfaction and employee commitment directly explain citizenship behavior. The following research questions developed:

RQ 1: Does job satisfaction influence citizenship behavior?

RQ 2: Does job satisfaction exhibit spiral effect on citizenship behavior via commitment?

The present study contributes by advancing the existing knowledge in a numerous way. First, there is a growing debate on the role of job satisfaction as it is studied both like the outcome and antecedents to organizational commitment, and citizenship behavior (Nguni et al., 2007). The present study will unearth the role of job satisfaction with organizational commitment and citizenship behavior. Second, the existing literature is loaded with the reviews on job satisfaction as an outcome variable; however, we incline to gauge its impact on an endogenous variable. Third, there are few studies noted on job satisfaction in only banking (Islam, Mohajan, \& Datta, 2011; Rahaman, 2012) and educational sector (Jahangir, Akbar, \& Begum, 2006). Surprisingly, no studies yet documented in readymade garments industries. Finally, the present study tested a mediated mediation effect, which is not tested elsewhere in the world. In this vein, we investigate if there is an indirect effect of organizational commitment on job satisfaction and positive deviance relationships.

\section{Literature Review}

\subsection{Job Satisfaction}

Job satisfaction is a positive or pleasurable state of feelings of an employee's job experiences. Locke (1976, p. 1300) defined job satisfaction as "a pleasurable or positive emotional state resulting from the self-appraisal of one's job or job experiences." He also reiterated the common factors of job satisfaction that included "work, pay, promotions, recognition, benefits, working conditions, supervision, co-workers, company and management" (p. 1302). Social exchange theory assumes that an organization needs to boost up a sharing environment among employees, organization, management, and other concerns (Topa, Guglielmi, \& Depolo, 2014). The higher social exchange ensures 
stronger employees' contribution and commitment, which results in better individual and team performance. The stronger relationship between job satisfaction and employees' loyalty (Ćulibrk et al., 2018; Mihaela, 2014; Peng, 2014) makes the workforce happier and more productive (Edwards et al., 2008). When employees notice that their perceived organizational support gets attention, Aslan, Shaukat, Ahmed, Shah, and Mahfar (2014) found their (employees) reciprocal consequent positive outcomes in the form of commitment, satisfaction and citizenship behaviors have been improved (Ababneh \& Hackett, 2019; Lambert et al., 2018).

\subsection{Organizational Commitment}

Organizational commitment is a kind of passion of an employee for being identified with the organization. Meyer and Allen (1991) narrated it as a psychological association between an organization and its employees in which the former is less likely to leave. It has been narrowed down into affective, continuance, and normative commitment. Affective commitment is the passionately involved with organization and employee is least likely to leave, continuance commitment is to weigh stay or leave and finally choose to stay, and ultimately normative commitment is the kind moral or ethical obligation from employees sides to stay (Veličković et al., 2014). Thus, it is a psychological connection of an employee with the organization to stay and being identified with the organization where he/ she works.

\subsection{Citizenship Behavior}

Although deviant behavior brings untold sufferings to the organization, there are some exceptions to it. Some deviances, for example, positive deviances (Spreitzer \& Sonenshein, 2004), constructive (Vadera, Pratt, \& Mishra, 2013), pro-social behavior (Carlo et al., 2014), extra-role behavior (Katz \& Kahn, 1978) brings positive repercussion to an organization. Citizenship behaviors like innovative behavior, whistleblowing, noncompliance with dysfunctional directives, and criticizing incompetent superiors. Organizational citizenship behavior is a kind of voluntary action by the employees to enhance and improve the organizational performance which is not required by their formal job requirements. Presently, organizations are facing enormous pressures from many corners and employees who can think proactively and contribute out of the box are critically demanded (Murphy, Athanasou, \& King, 2002).

\section{Development of Hypothesis}

Yen and Teng (2013, p. 401) said that "in today's struggling global economy, it is not enough for employees to merely do their jobs. Many businesses expect organizational members not only to complete their required duties but also proactively assist their colleagues." The citizenship behavior is crucial to the survival of an organization, and furthermore, it leads to the active and effective functioning of an organization (Murphy et al., 2002). Previous studies found how job satisfaction contributes to the citizenship behavior (Foote \& Tang, 2008; Nadiri \& Tanova, 2010; Paillé, Bourdeau, \& Galois, 2010; Zhang \& Cun, 2012). Social exchange theory over economic exchange theory interprets that only a satisfied employee being experience with organizational support is intended to do more than what an individual is expected. So, it can be hypothesized that job satisfaction leads to citizenship behavior. The hypothesis is given below:

H1: Job satisfaction has a direct influence on organizational citizenship behavior.

Employees backed by job satisfaction likely to contribute to organizational well-being. Job satisfaction is considered as the antecedents to organizational commitment (De Gieter, Hofmans, \& Pepermans, 2011; Hayati \& Caniago, 2012; Namasivayam \& Zhao, 2007; Yucel \& Bektas, 2012). Aslan et al. (2014) report that satisfied employees are always motivated and committed to the organization. Job satisfaction influences organizational commitment. There are many studies which noted that job satisfaction and organizational commitment are reciprocally and positively correlated (Wu \& Norman, 2006). Golden and Veiga (2008) opine that employees with highly committed are likely to be identified with their organization and tend to contribute to organizational performance. Positive organizational behavior produces satisfied and committed employees for achieving team as well as organizational outcomes (West, Patera, \& Carsten, 2009). Yeh (2014) find that job satisfaction and organizational commitment lead an employee to be more loyal and well-performing. Some research shows that satisfied employees being committed to aligning themselves with the group and broad organizational goals. There is an anecdotal belief that job satisfaction is related to regulatory outcome (Politis John, 2006); however, job satisfaction contributes to the enhancement of commitment and ends up with improved performance. Now, a hypothesis can be formed in this regard:

H2: Job satisfaction has a substantial influence on organizational commitment.

Social exchange theory reports that committed employees undergo greater interest to serve the organization more than they are ought to (Fan, Mahmood, \& Uddin, 2019). Kim and Brymer (2011) documented that a high commit- 
ment of employees encourages to do a more extra-role performance that, in turns, leads to engage in pro-social behavior. There is evidence that when employees are treated well, they feel the compulsion to reciprocate by helping the organization and well-being (Van Dyne, Graham, $\&$ Dienesch, 1994). On the other hand, if the employees do not trust the organization, organizational commitment does not grow much among them which demotivates them to decline their citizenship behavior (Mamman, Kamoche, \& Bakuwa, 2012). Study of Ng and Feldman (2011) also reported that committed employees like to go an extra mile and do beyond they are expected to do, such as helping their coworkers. Therefore, organizational commitment can be ended up in increased citizenship behavior (Uddin et al., 2019). The third hypothesis is designed hereafter.

H3: The is a direct influence of organizational commitment on organizational citizenship behavior.
Following the essence of the SET, it is stated that employees with the satisfaction from the job experiences more organizational commitment which obligates to serve the organization more than they are ought to (Blau, 1964; Homans, 1958). Accordingly, employees who are treated well by the organization will feel a moral obligation reciprocate for the wellbeing of the organization (Dyne \& Ang, 1998). Study of Ng and Feldman (2011) also reported that committed employees, which is derived from job satisfaction like to go the extra mile and do beyond they are expected to do. Henceforth, it can be hypothesized that job satisfaction would have influenced the employees' citizenship behavior through indirectly impacting organizational commitment.

H4: OC mediates the association between organizational job satisfaction and citizenship behavior.

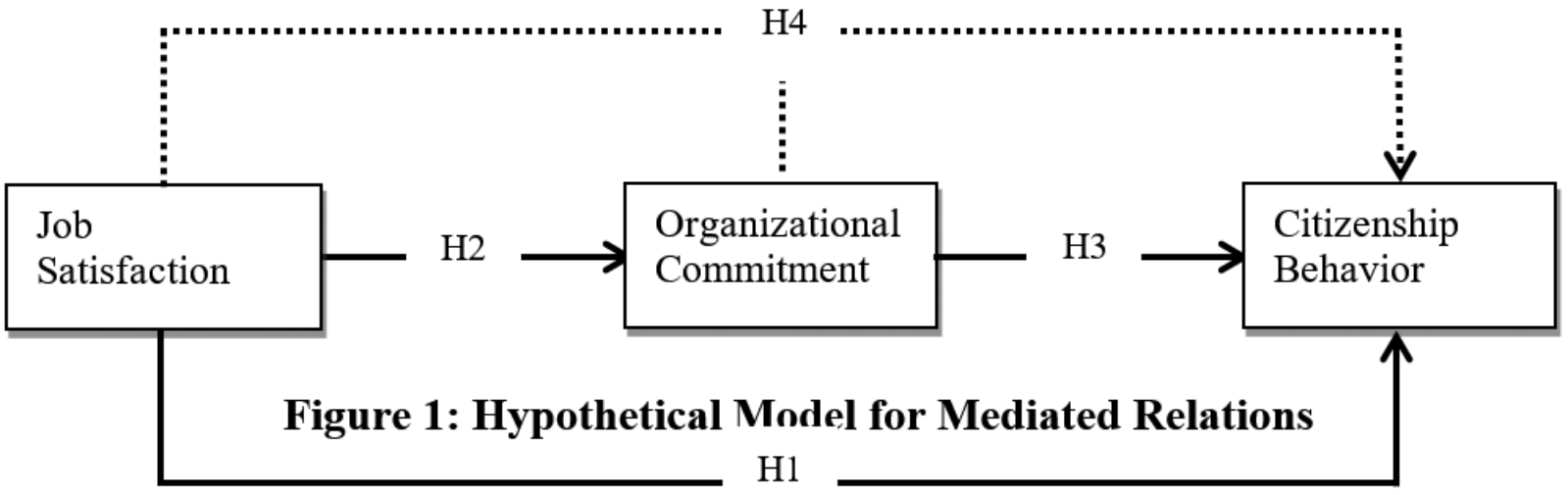

Figure 1: Hypothetical Model for Mediated Relations

\section{Research Methods}

\subsection{Participants and Data Collection Procedure}

The present study conducted among the executives of the RMG sector, which is the most significant contributor to the economy of Bangladesh. Accordingly, the population of the study is the executives working at various departments in RMG. We purposively selected RMG manufacturing firms as a sample from Chittagong Export Processing Zone, which is the largest export processing zone in the commercial capital, Chattogram-financial hub of Bangladesh (Azim, Fan, Uddin, Jilani, \& Begum, 2019).

We collected 221 responses, and 205 from them have been used in this research. Around $210(73.66 \%)$ usable responses were received out of 300 informants. Survey instruments were administered to respondents' end through a personal visit and electronic mail. Convenience sampling method has been used, and the respondents were briefed about their approaches to respond to the survey. Smart PLS-2 and IBM SPSS version-20 were used to execute the results. Table 1 exhibits the demographic profile of the respondents according to the variables of gender, marital status, age, educational records, and tenure. Table 1 displays the demographic information of the respondents. 
Table 2: Items building types of innovations

\begin{tabular}{|l|c|c|c|}
\hline Variables & Aspects & Frequencies & Percentage \\
\hline \multirow{3}{*}{ Gender } & Male & 155 & 76 \\
& Female & 50 & 24 \\
\hline \multirow{3}{*}{ Marital Status } & Married & 132 & 65 \\
& Single & 73 & 35 \\
\hline \multirow{5}{*}{ Tenure } & Bachelor & 37 & 18 \\
& Master & 153 & 75 \\
& Others & 15 & 7 \\
\hline \multirow{5}{*}{ Age } & Above 1 year & 23 & 11 \\
& Above 5 years & 93 & 45 \\
& Above 10 years & 75 & 37 \\
& Above 15 years & 14 & 7 \\
& Above 20 years & 17 & 46 \\
& Above 25 years & 79 & 36 \\
& Above 30 years & 73 & 10 \\
\hline
\end{tabular}

\subsection{Measurement Tools}

We have collected three measurement tools from prior studies (Appendix 1). Job satisfaction is measured by Quinn and Mangione (1973), citizenship behavior by Ritz, Giauque, Varone, and Anderfuhren-Biget (2014), and organizational commitment by Mowday, Steers, and Porter (1979).

\subsubsection{Job Satisfaction}

Respondents were asked to respond against each item on a 5 -point Likert scale $(1=$ strongly agree........ $5=$ strongly disagree). A sample item for this scale was: "All in all, I am satisfied with my job."

\subsubsection{Organizational Commitment}

We have used 9-item to represent the organizational commitment, and each of the informants was asked to rate each item on a 5 -point Likert scale $(1=$ strongly agree........ 5 = strongly disagree). A sample item for this scale was: "I talk to my friends that this organization is a great place to work."

\subsubsection{Organizational Citizenship Behavior}

5-item OCB construct was used and each respondent was asked to select each item on a 5-point Likert scale $(1=$ strongly agree....... $5=$ strongly disagree). A sample item for this scale was: "I try hard to help others so they can become integrated with my organization."

\section{Evaluation of the Model}

The study used partial least square based structural equation modeling (PLS-SEM) in place of simple regression-based analysis. The merit of this analytic technique demonstrates an integrated model which delineates the robustness and accuracy of the estimates (Fan et al., 2019; Mahmood, Uddin, \& Luo, 2019). The supremacy of the PLS-SEM lies in measuring the influence of endogenous variables on exogenous variables, and also the precise detection of measurement errors (Dediu, Leka, \& Jain, 2018). SmartPLS2 is used to test both the measurement model and the structural model (Hair Jr, Hult, Ringle, \& Sarstedt, 2014). 
Table 2: Reliabilities and Validities of the Measurement Tools

\begin{tabular}{|l|c|c|c|c|c|}
\hline Variables & $\mathbf{1}$ & $\mathbf{2}$ & $\mathbf{3}$ & CR & AVE \\
\hline 1. Job satisfaction & $\mathbf{0 . 7 9 5}$ & & & 0.831 & 0.632 \\
2. Organizational commitment & 0.700 & $\mathbf{0 . 7 7 3}$ & & 0.789 & 0.598 \\
3. Citizenship behavior & 0.534 & 0.572 & $\mathbf{0 . 8 5 3}$ & 0.832 & 0.727 \\
\hline
\end{tabular}

CR. Composite Reliability and AVE. Average Variance Extracted.

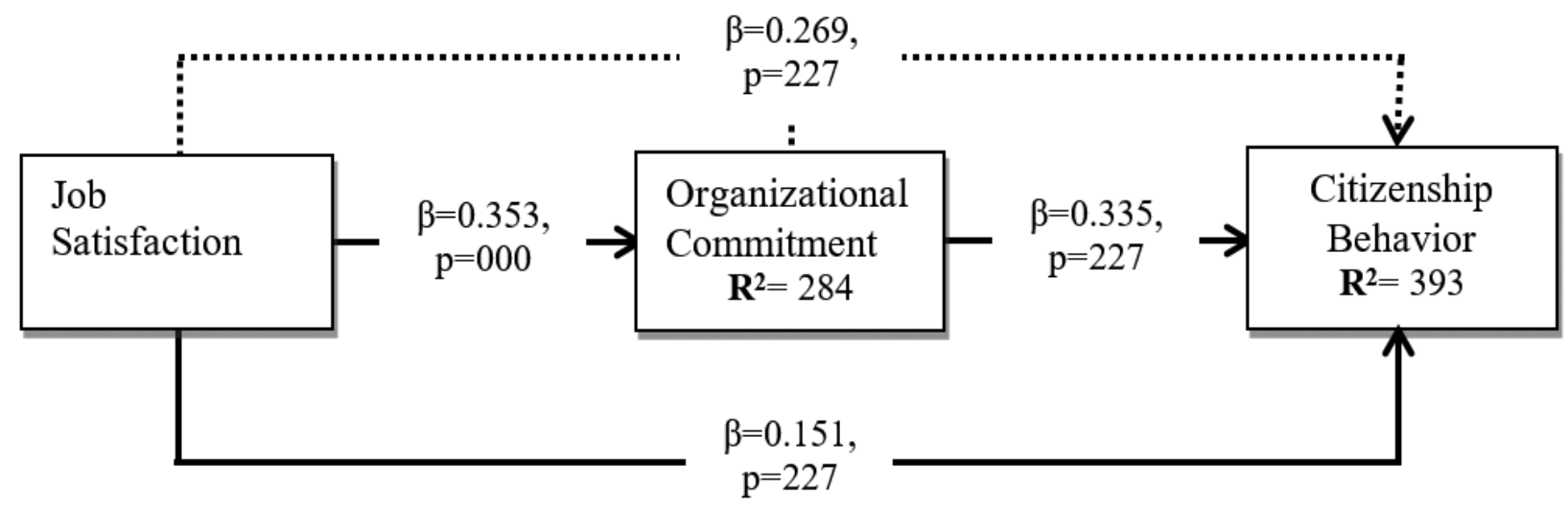

Figure 2: Path estimates in a structural model

\subsection{Measurement model}

We have tested both the validity and reliability measures. For reliability issue, composite reliability (CR) test has been performed (Alam \& Uddin, 2019; Howladar, Rahman, \& Uddin, 2018). For the authenticity of the validity issues, both the convergent and discriminant validities were advocated (Azim et al., 2019; Ringle, Wende, $\&$ Will, 2005). Table 2 demonstrated that the constructs are reliable and validity is candidly reflected that all constructs pass through both validity tests. It is observed that the minimum average variance extracted $(\mathrm{AVE}=0.598)$, and CR (0.789) are above the threshold value of 0.500 and 0.700 respectively (Hair Jr., Hult, Ringle, \& Sarstedt, 2014; Saunders, Lewis, \& Thornhill, 2009). Thus, these measurement tools' convergent validity is guaranteed. For testing the discriminant validity, we scrutinized the square root of AVE of each observed variables against their corresponding variables' correlation scores. The diagonal value, in table 2, representing the correlation between the same measures in the correlation matrix table is higher than the relationship with other variables. Hence, all the measuring tools are discriminately valid as well (Ringle, Da Silva, \& Bido, 2014). Moreover, the loading of each item is checked (Appendix 1) and the minimum loading of any item is 0.712 , which is above the threshold level (Das, Biswas, Jilani, \& Uddin, 2019; Ringle et al., 2014; Yi, Uddin, Das, Mahmood, \& Sohel, 2019).

\subsection{Structural model}

We tested the structured model from multiple perspectives to ensure global fitness (Fan et al., 2019; Mahmood et al., 2019; Uddin et al., 2019). Apart from just estimating path estimates $(\beta)$ and their significance levels, we also assessed the coefficient of determination (R2), and the goodness of fit (GFI) which is advocated by Wetzels, Odekerken-Schröder, and Van Oppen (2009). Bootstrapping 5000 sample cases were used to generate the hypothesis estimates. Figure 2 exhibited that the minimum strength of the influence $(\beta>0.151)$ and overall predictive value (R2) of the entire model are above the threshold limit (more than 0.26 effect size is substantial) (Cohen, 1977, 1988) excepting the direct path (job satisfaction $\square$ citizenship behavior) fixes at 0.151 due to the mediated mediation effect of organizational commitment.

Finally, the study estimated the GoF, which is the square root of the average communality times average R2. In line with the study of Tenenhaus, Vinzi, Chatelin, and Lauro (2005), the estimates reported in Equation (1) demonstrated that the GoF value is 0.470 . Cohen (1977, 1988) exhibited the GoF value above 0.36 is substantial on the condition that minimum communality must be above 0.50 (Fornell \& Larcker, 1981). The present study observes that minimum communality value is 0.598 and reported GoF 0.47, which is substantial for a given study (Cohen, 1977, 1988). 


\section{Results}

$$
\begin{aligned}
& \text { GoF }=\sqrt{\text { Average communality } \times \text { average } R^{2}} \\
& G o F=\sqrt{0.652 \times 0.339} \\
& G o F=0.470
\end{aligned}
$$

The study divided the findings into unmediated and mediated analysis in a structured model. Table 3 exhibited that the direct effects of exogenous variables on endogenous variables. In $\mathrm{H} 1$, it is observed that the influence $(\beta=0.151$, $\mathrm{p}<0.227$ ) of job satisfaction on citizenship behavior is insignificant. Thus H1 is not supported. The result is not consistent with the previous empirical findings globally (Paillé et al., 2010; Van Dyne et al., 1994). In H2, it is hypothesized that job satisfaction has a significant influence on organizational commitment. The result reported that the effect size $(\beta=0.353, p<0.000)$ of job satisfaction on organizational commitment is substantial. Thus, $\mathrm{H} 2$ is supported. Studies of Yucel and Bektas (2012), Kim and Brymer (2011), and Lambert et al. (2018) also observed that job satisfaction has a marked influence on organizational commitment. Finally, in H3, we have hypothesized that organizational commitment impacts citizenship behavior. The estimates $(\beta=0.335, \mathrm{p}>0.000)$ demonstrated that organizational commitment is also significant. Hence, this hypothesis is also supported. This result is also found consistent with the prior results (Mamman et al., 2012; Ng
\& Feldman, 2011).

In $\mathrm{H} 4$, it is hypothesized that organizational commitment mediates the association between job satisfaction and organizational citizenship behavior. To estimate the mediation effect, we have measured the direct impact before mediation and after mediation. According to Hayes (2013) and Baron and Kenny (1986), to have full mediation effect, a significant direct path (c) before adding the mediator variables must be insignificant $(\mathrm{c} /)$ after adding the mediator variables. Table-4 highlighted that direct effect (c) before running the mediator variable was significant $(\beta=0.532, p>0.000)$. However, immediate effect $(c /)$ after adding mediator variable becomes insignificant $(\beta=0.151$, $p>0.227$ ). Thus, there is a full mediation effect of organizational commitment on the relationship between job satisfaction and citizenship behavior. The result is also found consistent with the outcome of Uddin et al. (2019).

Table 3: Estimates on direct effects in an unmediated model

\begin{tabular}{|c|c|c|c|c|c|c|c|}
\hline Hypothesis & Path & Mediator & $\begin{array}{l}\text { Direct } \\
\text { Effect }\end{array}$ & $\begin{array}{c}\text { Indirect } \\
\text { Effect }\end{array}$ & $\begin{array}{c}\text { Total } \\
\text { Effect }\end{array}$ & Comments & t-value ( $p$-value) \\
\hline \multirow{4}{*}{$\mathrm{H} 4$} & $\mathrm{JS} \rightarrow \mathrm{CB}(\mathrm{c})$ & \multirow[b]{4}{*}{$\mathrm{OC}$} & 0.532 & & \multirow[b]{4}{*}{0.269} & \multirow{4}{*}{ Full Mediation } & $7.493(\mathrm{p}<0.000)$ \\
\hline & $\mathrm{JS} \rightarrow \mathrm{OC}$ (a) & & & 0.353 & & & $6.435(\mathrm{p}<0.000)$ \\
\hline & $\mathrm{OC} \rightarrow \mathrm{CB}(\mathrm{b})$ & & & 0.335 & & & $4.224(\mathrm{p}<0.000)$ \\
\hline & $\mathrm{JS} \rightarrow \mathrm{CB}(\mathrm{c})$ & & 0.151 & 0.118 & & & $1.212(\mathrm{p}<0.227)$ \\
\hline
\end{tabular}

\begin{tabular}{|c|c|c|c|c|c|}
\hline Hypothesis & Path Relations & Estimate & $\begin{array}{c}\text { Critical } \\
\text { Ratio }\end{array}$ & p.Value & Result \\
\hline H1 & JS $\rightarrow$ CB & 0.151 & 1.212 & 0.227 & Not supported \\
\hline H2 & JS $\rightarrow$ OC & 0.353 & 6.435 & $* * *$ & Supported \\
\hline H3 & OC $\rightarrow$ CB & 0.335 & 4.224 & $* * *$ & Supported \\
\hline
\end{tabular}

JS. Job satisfaction, CB. Citizenship behavior, OC. Organizational Commitment.

Table 4: Mediating effect of organizational commitment

JS. Job satisfaction, CB. Citizenship behavior, OC. Organizational Commitment, Indirect effect. a times b, and Total effect = direct effect + indirect effect. 


\section{Discussion}

The study aimed to examine the impact of job satisfaction on organizational commitment and citizenship behavior in the RMG industries in Bangladesh. Additionally, it also investigated the indirect influence of job satisfaction, via organizational commitment, on citizenship behavior. Henceforth, the present integrated hypothetical model test four different hypotheses basing on the conceptualization of SET. The usage of a correlation matrix, PLS-SEM, and mediation effect analyses were purported to find out the testimonies of the accurate gauging. Correlation matrix showed that all the observed variables are correlated with each other which is found consistent with the global findings at different contexts (Claudia, 2018; Jahangir et al., 2006; Kim \& Brymer, 2011; Nguni et al., 2007; Williams \& Anderson, 1991).

Despite the fact that job satisfaction is a pressing vaccine to engage employees' organizational commitment toward citizenship behavior, the influence of it-job satisfaction-on citizenship behavior is not significantly aligned. Thus, the H1-the impact of job satisfaction on citizenship behavior-is not supported. Unlike the previous findings of (Jahangir et al., 2006; Kim \& Brymer, 2011; Nguni et al., 2007), our conclusion is also supported by the results of Claudia (2018); Williams and Anderson (1991). These findings of the present study are consistent with the prior results because of the presence of the mediator variable-organizational commitment. $\mathrm{H} 2$ proposed a significant direct effect of job satisfaction on organizational commitment. The studied result also demonstrated the significant positive impact signifying that the proposed hypothesis is supported. In line with the conceptualization of SET, it posits that job satisfaction facilitates employees' commitment toward their organization. The result is also found consistent with prior studies in other settings (Ćulibrk et al., 2018; Lambert et al., 2018).

Furthermore, it is hypothesized, in H3, that organizational commitment stimulates employees' participation in voluntary citizenship behavior. Empirical result invigorates the previous empirical findings to the fact that organizational commitment has a significant influence on citizenship behavior. Thus, H3 is also supported. We observed the similar results of the impact of organizational commitment on citizenship behavior since the organizational commitment of employees drives them to escalate the firm values and image through taking participation in pro-organizational activities. The findings of Afsar, Shahjehan, Cheema, and Javed (2018), Lee, Woo, and Kim (2018), Uddin et al. (2019), and Howladar (2017) showed the similar estimates on this proposed hypothesis.

Finally, the indirect of organizational commitment is postulated as such organizational commitment mediates the impact of job satisfaction on citizenship behavior. The estimates on the mediation effect accentuate that the indi- rect effect is significant. However, the previous considerable influence or direct impact (before using the mediating variable) turns into negative after the usage of the mediating variable (organizational commitment). It strengthens the understanding that organizational commitment fully mediates the association between job satisfaction and citizenship behavior (Claudia, 2018). The rationale behind the significant indirect influence can be reckoned in a way that job satisfaction of an employee inclines to enhance organizational commitment which results in citizenship behavior (Claudia, 2018; Jahangir et al., 2006; Nguni et al., 2007). Similarly, the underpinning SET underscores that a perceived positive, rewarding environment escalates one obligation to reciprocate to benefactors. Using the lenses of empirical investigation and theoretical significance, $\mathrm{H} 4$ is also supported.

\section{Conclusion}

\subsection{Strengths and contributions of the study}

The study contributes to advance knowledge in various ways. Ideally, it postulates that the organization must try its level best to lift the employees' job satisfaction level to improve their organizational commitment level, which will augment their engagement in citizenship behavior. The integrated structural model sheds light on the usage of the three observed variables in a comprehensive way rather than using solitarily. Unlike the study of Williams and Anderson (1991), our study declares premium on using the three variables, i.e., job satisfaction, organizational commitment, and citizenship behavior, in a mediated relationship where job satisfaction indirectly stimulates employees' to actively participate in citizenship behavior through improving their organizational commitment. Following the rationale drawn from the study Homans (1958) and Blau (1964) regarding SET, it is lucid enough to candidly saying that organization's positive initiative instigating employees' job satisfaction will result in driving organizational commitment toward pro-organizational proactivity. The dearth of the literature on the variables above in Bangladesh setting guarantees the novelty of the present study because the newly estimated result in other settings/contexts will validate and generalize the previous findings (Manish et al., 2018). Finally, the study also fills the vacuum of scientific observations of the cause and effect relationship among job satisfaction, organizational commitment, and citizenship behavior in a very burgeoning industry-RMG. 


\subsection{Managerial Implications}

Several managerial implications can be framed from this empirical study. Although disastrous movements by the RMG employees is substantially frequent since the inauguration of RMG industries in Bangladesh, minimal effort has been paid to unearth the critical reasons from employees' perspective. Notably, no endeavor has been evident yet that soars up employees' commitment and job satisfaction leading toward citizenship behavior. The present study demonstrates the influence of job satisfaction and commitment, directly and indirectly, contributes to a pro-organizational attitude among the employees. Thus, the manager must expose to take more initiative to redefine the working environment that builds and develops a lasting positive impression among the employees. Unlike the findings in dissimilar contexts, (Claudia, 2018; Jahangir et al., 2006; Nguni et al., 2007; Williams \& Anderson, 1991), the present finding corroborate with the prior results to the fact that organizations must display requisite assistance and persistence on employees' endeavor to foster their citizenship initiative.

\subsection{Limitations and future directions}

The study attempts to draw the direct effects of job satisfaction and organizational commitment on organizational citizenship behavior, and also the indirect impact (mediating) of organizational commitment on the association between job satisfaction and organizational citizenship behavior. Although all the hypotheses are supported in this study, it is subject to several limitations which indirectly demonstrate the directions for future research. The generalizability of result might be achieved if we could replace the convenience sampling with the random sampling method. The sample size poses a significant limitation. A large sample size $(>205)$ might yield more representation findings. To facilitate the causality of the results, longitudinal data over cross-sectional data is preferred. Further research on the relationships among employee engagement, organizational commitment, and citizenship behavior moderated by demographic factors is advised. The very burgeoning constraint of this study is the ignorance of the moderating variables affecting those observed relationships. Hence, future researchers are recommended to incorporate the impact of intervening effects on the aforesaid relationships.

\section{Literature}

Ababneh, K. I., \& Hackett, R. D. (2019). The direct and indirect impacts of job characteristics on faculty organizational citizenship behavior in the United Arab Emirates (UAE). Higher Education, 77(1), 1936. http://dx.doi.org/10.1007/s10734-018-0252-3
Afsar, B., Shahjehan, A., Cheema, S., \& Javed, F. (2018). The Effect of perceiving a calling on Pakistani nurses' organizational commitment, organizational citizenship behavior, and job Stress. Journal of Transcultural Nursing, 29(6), 540-547. http://dx.doi.org/10.1177/1043659618761531

Ahmed, S., Hasanuzzaman, M., Chowdhury, M. S. I., Shaikh, M. E., \& Munir, M. S. (2018). A survey on the factors affecting employee turnover in the readymade garments of Bangladesh. Global Journal of Research in Engineering, 18(1), 47-52.

Alam, M. N., Azim, M. T., \& Alias, R. B. (2017). Social compliance in ready-made garment industry in Bangladesh: Challenges for HR personnel. Journal of Applied Environmental and Biological Science, 7(10), 8-18.

Alam, M. S., \& Uddin, M. A. (2019). Adoption and implementation of enterprise resource planning (ERP): An empirical study. Journal of Management and Research, 6(1), 84-116. Aslan, A. S., Shaukat, M. Z., Ahmed, I., Shah, I. M., \& Mahfar, M. (2014). Job satisfactions of academics in malaysian public universities. Procedia - Social and Behavioral Sciences, 114, 154-158. http://dx.doi.org/10.1016/j.sbspro.2013.12.676

Azim, M. T., Fan, L., Uddin, M. A., Jilani, M. M. A. K., \& Begum, S. (2019). Linking transformational leadership with employees' engagement in the creative process. Management Research Review, 42(7), 837858. http://dx.doi.org/10.1108/MRR-08-2018-0286

Bakht, Z., \& Hossain, M. (2017). Workplace safety and industrial relations in the readymade garments $(R M G)$ industry in Bangladesh. Retrieved from Bangladesh: https://think-asia.org/handle/11540/7747

Baron, R. M., \& Kenny, D. A. (1986). The moderator-mediator variable distinction in social psychological research: Conceptual, strategic, and statistical considerations. Journal of Personality and Social Psychology, 51(6), 11731182. https://doi.org/10.1037//0022-3514.51.6.1173

Belwalkar, S., Vohra, V., \& Pandey, A. (2018). The relationship between workplace spirituality, job satisfaction and organizational citizenship behaviors - an empirical study. Social Responsibility Journal, 14(2), 410-430. http://dx.doi.org/10.1108/SRJ-05-2016-0096

Blau, P. M. (1964). Justice in social exchange. Sociological Inquiry, 34(2), 193-206. https://doi.org/10.1111/j.1475-682X.1964.tb00583.x

Carlo, G., Mestre, M. V., McGinley, M. M., Tur-Porcar, A., Samper, P., \& Opal, D. (2014). The protective role of prosocial behaviors on antisocial behaviors: the mediating effects of deviant peer affiliation. Journal of Adolescence, 37(4), 359-366. http://dx.doi.org/10.1016/j.adolescence.2014.02.009 Claudia, M. (2018). The influence of perceived organizational support, job satisfaction and organizational commitment toward organizational citizen- 
ship behavior (a study of the permanent lecturers at University of Lambung Mangkurat, Banjarmasin). Journal of Indonesian Economy and Business, 33(1), 23-45. https://doi.org/10.22146/jieb.17761 Cohen, J. (1977). Statistical Power Analysis for the Behavioral Sciences. New York, NY: Academic Press.

Cohen,J.(1988).Statisticalpoweranalysisforthebehavioral sciences. Hillsdale, NJ: Lawrence Erlbaum Associates.

Ćulibrk, J., Delić, M., Mitrović, S., \& Ćulibrk, D. (2018). Job satisfaction, organizational Commitment and Job Involvement: The Mediating Role of Job Involvement. Frontiers in Psychology, 9(132). http://dx.doi.org/10.3389/fpsyg.2018.00132

Das, A. K., Biswas, S. R., Jilani, M. M. A. K., \& Uddin, M. A. (2019). Corporate environmental strategy and voluntary environmental behavior-mediating effect of psychological green climate. Sustainability, 11(11), 3123. http://dx.doi.org/10.3390/su11113123

Davia, M.A., \& Legazpe, N.(2018). Jobsatisfactionamongst academics: the role of research productivity AU -Albert, Cecilia. Studies in Higher Education, 43(8), 1362-1377. http://dx.doi.org/10.1080/03075079.2016.1255937

De Gieter, S., Hofmans, J., \& Pepermans, R. (2011). Revisiting the impact of job satisfaction and organizational commitment on nurse turnover intention: An individual differences analysis. International Journal of Nursing Studies, 48(12), 1562-1569. http://dx.doi.org/10.1016/j.ijnurstu.2011.06.007

Dediu, V., Leka, S., \& Jain, A. (2018). Job demands, job resources and innovative work behaviour: a European Union study. European Journal of Work and Organizational Psychology, 27(3), 310-323. http://dx.doi.org/10.1080/1359432x.2018.1444604

Dyne, L. V., \& Ang, S. (1998). Organizational citizenship behavior of contingent workers in Singapore. Academy of Management Journal, 41(6), 692-703. https://doi.org/10.5465/256965

Fan, L., Mahmood, M., \& Uddin, M. A. (2019). Supportive Chinese supervisor, innovative international students: a social exchange theory perspective. Asia Pacific Education Review, 20(1), 101-115. http://dx.doi.org/10.1007/s12564-018-9572-3

Foote, D. A., \& Tang, T. L. P. (2008). Job satisfaction and organizational citizenship behavior (OCB). Management Decision, 46(6), 933-947. http://dx.doi.org/10.1108/00251740810882680

Fornell, C., \& Larcker, D. F. (1981). Evaluating structural equationmodels withunobservablevariables andmeasurement error. Journal of Marketing Research, 18(1), 3950. http://dx.doi.org/10.1177/002224378101800104

Golden, T. D., \& Veiga, J. F. (2008). The impact of superior-subordinate relationships on the commitment, job satisfaction, and performance of virtual workers. The Leadership Quarterly, 19(1), 7788. http://dx.doi.org/10.1016/j.leaqua.2007.12.009

Hair Jr, J. F., Hult, G. T., Ringle, C. M., \& Sarstedt, M.
(2014). A primer on partial least squares structural equation modeling (PLS-SEM) SAGE Publications, Inc. Hair Jr., J. F., Hult, G. T. M., Ringle, C. M., \& Sarstedt, M. (2014). A primer on partial least squares structural equation modeling (PLS-SEM): SAGE Publications, Inc.

Hayati, K., \& Caniago, I. (2012). Islamic work ethic: The role of intrinsic motivation, job satisfaction, organizational commitment and job performance. Procedia - Social and Behavioral Sciences, 65(0), 11021106. http://dx.doi.org/10.1016/j.sbspro.2014.05.148

Hayes, A. F. (2013). Introduction to mediation, moderation, and conditional process analysis: A regression-based approach. NY: The Guilford Press.

Homans, G. C. (1958). Social behavior as exchange. American Journal of Sociology, 63(6), 597-606. https://doi.org/10.1086/222355

Howladar, M. H. R. (2017). Perceived servant leadership: Its role on the organizational commitment and organizational citizenship behavior in private commercial banks in Bangladesh. (Doctoral), University of Chittagong, Bangladesh. Howladar, M. H. R., Rahman, M. S., \& Uddin, M.A. (2018). Deviant workplace behavior and job performance: The moderating effect of transformational leadership. Iranian Journal of Management Studies, 11(1), 147-183. http://dx.doi.org/10.22059/ijms.2018.226143.672514

Islam, A. M. (2017, 23-12-2017). Why and how should you invest in Bangladesh RMG industry? TextileToday. Retrieved from https://textiletoday.com.bd/invest-bangladesh-rmg-industry/

Islam, J., Mohajan, H., \& Datta, R. (2011). A study on job satisfaction and morale of commercial banks in Bangladesh. International Journal of Economics and Research, 3(4), 152-172.

Jahangir, N., Akbar, M., \& Begum, N. (2006). The role of social power, procedural justice, organizational commitment, and job satisfaction to engender organizational citizenship behavior. ABAC Journal, 26(3), 21-36.

Katz, D., \& Kahn, R. L. (1978). The social psychology of organizations (Vol. 2). New York: John Wiley.

Kim, W. G., \& Brymer, R. A. (2011). The effects of ethical leadership on manager job satisfaction, commitment, behavioral outcomes, and firm performance. International Journal of Hospitality Management, 30(4), 10201026. http://dx.doi.org/10.1016/j.ijhm.2011.03.008

Lambert, E. G., Qureshi, H., Frank, J., Klahm, C., \& Smith, B. (2018). Job stress, job involvement, job satisfaction, and organizational commitment and their associations with job burnout among indian police officers: Aresearch note. Journal of Police and Criminal Psychology, 33(2), 85-99. http://dx.doi.org/10.1007/s11896-017-9236-y

Lee, Y. H., Woo, B., \& Kim, Y. (2018). Transformational leadership and organizational citizenship behavior: Mediating role of affective commitment. International Journal of Sports Science \& Coaching, 13(3), 373382. http://dx.doi.org/10.1177/1747954117725286 
Liu, H.-L., \& Lo, V.-h. (2018). An integrated model of workload, autonomy, burnout, job satisfaction, and turnover intention among Taiwanese reporters. Asian Journal of Communication, 28(2), 153-169. http://dx.doi.org/10.1080/01292986.2017.1382544

Locke, E. A. (1976). The nature and causes of job satisfaction. In M. D. Dunnette (Ed.), Handbook of industrial and organizational psychology (pp. 63 - 78 ). Chicago.

Mahmood, M., Uddin, M. A., \& Luo, F. (2019). Influence of transformational leadership on employees' creative process engagement: A multi-level analysis. Management Decision, 57(3), 741-764. http://dx.doi.org/10.1108/MD-07-2017-0707

Mamman, A., Kamoche, K., \& Bakuwa, R. (2012). Diversity, organizational commitment and organizational citizenship behavior: An organizing framework. Human Resource Management Review, 22(4), 285302. http://dx.doi.org/10.1016/j.hrmr.2011.12.003

Manish, K., Hemang, J., Ashish, R., \& Sandeep, S. (2018). Managerial support for development and turnover intention: Roles of organizational support, work engagement and job satisfaction. Journal of Organizational Change Management, 31(1), 135153. http://dx.doi.org/10.1108/JOCM-06-2017-0232

Meyer, J. P., \& Allen, N. J. (1991). A three-component conceptualization of organizational commitment. Human Resource Management Review, 1(1), 6189. https://doi.org/10.1016/1053-4822(91)90011-Z

Mihaela, P. L. (2014). Psychological variables to professional satisfaction for teachers. Procedia - Social and Behavioral Sciences, 127, 807-811. http://dx.doi.org/10.1016/j.sbspro.2014.03.359

Mowday, R. T., Steers, R. M., \& Porter, L. W. (1979). The measurement of organizational commitment. Journal of Vocational Behavior, 14(2), 224-247. http://dx.doi.org/10.1016/0030-5073(73)90002-0

Muhammad, A. (2015). Workers' Lives, Walmart's Pocket. Economic and Political Weekly, 50, 143-150.

Murphy, G., Athanasou, J., \& King, N. (2002). Job satisfaction and organizational citizenship behaviour: A study of Australian human-service professionals. Journal of Managerial Psychology, 17(4), 287297. http://dx.doi.org/10.1108/02683940210428092

Nadiri, H., \& Tanova, C. (2010). An investigation of the role of justice in turnover intentions, job satisfaction, and organizational citizenship behavior in hospitality industry. International Journal of Hospitality Management, 29(1), 33-41. http://dx.doi.org/10.1016/j.ijhm.2009.05.001

Namasivayam, K., \& Zhao, X. (2007). An investigation of the moderating effects of organizational commitment on the relationships between work-family conflict and job satisfaction among hospitality employees in India. Tourism Management, 28(5), 1212-1223. http://dx.doi.org/10.1016/j.tourman.2006.09.021

Ng, T. W. H., \& Feldman, D. C. (2011). Affective orga- nizational commitment and citizenship behavior: Linear and non-linear moderating effects of organizational tenure. Journal of Vocational Behavior, 79(2), 528-537. http://dx.doi.org/10.1016/j.jvb.2011.03.006

Nguni, S., Sleegers, P., \& Denessen, E. (2007). Transformational and transactional leadership effects on teachers" job satisfaction, organizational commitment, and organizational citizenship behavior in primary schools: The Tanzanian case. School Effectiveness and School Improvement, 17(2), 145177. http://dx.doi.org/10.1080/09243450600565746

Paillé, P., Bourdeau, L., \& Galois, I. (2010). Support, trust, satisfaction, intent to leave and citizenship at organizational level. International Journal of Organizational Analysis, 18(1), 41-58. http://dx.doi.org/10.1108/19348831011033203

Peng, Y.-P. (2014). Job satisfaction and job performance of university librarians: A disaggregated examination. Library \& Information Science Research, 36(1), 74-82. http://dx.doi.org/10.1016/j.lisr.2013.02.006

Politis John, D. (2006). Self-leadership behavioural-focused strategies and team performance. Leadership \&amp; Organization Development Journal, 27(3), 203216. http://dx.doi.org/10.1108/01437730610657721

Quinn, R. P., \& Mangione, T. W. (1973). Evaluating weighted models of measuring job satisfaction: A Cinderella story. Organizational Behavior and Human Performance, 10(1), 1-23. http://dx.doi.org/10.1016/0030-5073(73)90002-0

Rahaman, H. S. (2012). Organizational commitment, perceived organizational support, and job satisfaction among school teachers: Comparing public and private sectors in Bangladesh. South Asian Journal of Management, 19(3), 7-17.

Rahman, M. H., \& Siddiqui, S. A. (2015). RMG: Prospect of contribution in economy of Bangladesh. International JournalofScientificandResearchPublications, 5(9), 1-8.

Ringle, C. M., Da Silva, D., \& Bido, D. d. S. (2014). Structural equation modeling with the SmartPLS. Brazilian Journal of Marketing, 13(2), 56-73.

Ringle, C. M., Wende, S., \& Will, A. (2005). SmartPLS 2. Hamburg: SmartPLS.

Ritz, A., Giauque, D., Varone, F., \& Anderfuhren-Biget, S. (2014). From leadership to citizenship behavior in public organizations: When values matter. Review of Public Personnel Administration, 34(2), 128-152. https://doi.org/10.1177/0734371x14521456

Saunders, M., Lewis, P., \& Thornhill, A. (2009). Research Methods for Business Students (5th ed.). England Pearson Education Limited. Shadat, W. B., Rahman, M. T., Rahman, K. M., \& Hawlader, A. (2016). Cost benefit analysis of RMG compliance to increasing presence of ready made garments ( $R M G$ ) and new specialized RMG industry zone: Bangladesh priorities. Retrieved from https://www.copenhagenconsensus.com/sites/default/files/bin shadat rmg.pdf 
Smith, T. D. (2018). An assessment of safety climate, job satisfaction and turnover intention relationships using a national sample of workers from the USA. International Journal of Occupational Safety and Ergonomics, 24(1), 27-34. http://dx.doi.org/10.1080/10803548.2016.1268446

Spreitzer, G. M., \& Sonenshein, S. (2004). Toward the construct definition of positive deviance. American Behavioral Scientist, 47(6), 828-847. http://dx.doi.org/10.1177/0002764203260212

Stoermer, S., Haslberger, A., Froese, F. J., \& Kraeh, A. L. (2018). Person-environment fit and expatriate job satisfaction. Thunderbird International Business Review, 60(6), 851-860. http://dx.doi.org/10.1002/tie.21920

Tenenhaus, M., Vinzi, V. E., Chatelin, Y.-M., \& Lauro, C. (2005). PLS path modeling. Computational Statistics \& Data Analysis, 48(1), 159205. https://doi.org/10.1016/j.csda.2004.03.005

Topa, G., Guglielmi, D., \& Depolo, M. (2014). Mentoring and group identification as antecedents of satisfaction and health among nurses: What role do bullying experiences play? Nurse Education Today, 34(4), 507512. http://dx.doi.org/10.1016/j.nedt.2013.07.006

Uddin, M. A., Mahmood, M., \& Fan, L. (2019). Why individual employee engagement matters for team performance? Mediating effects of employee commitment and organizational citizenship behaviour. Team Performance Management: An International Journal, 25(1/2), 47-68. http://dx.doi.org/10.1108/TPM-12-2017-0078

Uddin, M. A., Rahman, M. S., \& Howladar, M. H. R. (2014). Exploring the relationships among transformational leadership, deviant workplace behavior, and job performance: An empirical study. ABAC Journal, 34(1), 1-12.

Vadera, A. K., Pratt, M. G., \& Mishra, P. (2013). Constructive deviance in organizations: Integrating and moving forward. Journal of Management. 39(5), 1221-276. https://doi.org/10.1177/0149206313475816

Van Dyne, L., Graham, J. W., \& Dienesch, R. M. (1994). Organizational citizenship behavior: Construct redefinition, measurement, and validation. Academy of Management Journal, 37(4), 765-802. https://doi.org/10.5465/256600

Veličković, V. M., Višnjić, A., Jović, S., Radulović, O., Šargić, Č., Mihajlović, J., \& Mladenović, J. (2014). Organizational commitment and job satisfaction among nurses in Serbia: A factor analysis. Nursing Outlook, 62(6), 415-427. http://dx.doi.org/10.1016/j.outlook.2014.05.003

Wadud, Z., \& Huda, F. Y. (2017). Fire safety in the readymade garment sector in Bangladesh: Structural inadequacy versus management deficiency. Fire Technology, 53(2), 793-814. http://dx.doi.org/10.1007/s 10694-016-0599-x

Wadud, Z., Huda, F. Y., \& Ahmed, N. U. (2014). Assessment of fire risk in the readymade garment industry in Dhaka, Bangladesh. Fire Technology, 50(5), 1127-
1145. http://dx.doi.org/10.1007/s10694-013-0349-2 West, B. J., Patera, J. L., \& Carsten, M. K. (2009). Team level positivity: investigating positive psychological capacities and team level outcomes. Journal of Organizational behavior, 30(2), 249-267.

http://dx.doi.org/10.1002/job.593

Wetzels, M., Odekerken-Schröder, G., \& Van Oppen, C. (2009). Using PLS path modeling for assessing hierarchical construct models: Guidelines and empirical illustration. MIS Quarterly, 33(1), 177-195. https://doi.org/10.2307/20650284

Williams, L. J., \& Anderson, S. E. (1991). Job Satisfaction and Organizational Commitment as Predictors of Organizational Citizenship and In-Role Behaviors. Journal of Management, 17(3), 601-617. http://dx.doi.org/10.1177/014920639101700305

WTO. (2018). World Trade Statistical Review. Retrieved from https:/www.wto.org/english/ res_e/statis_e/wts 2018 _e/wts 18 toc_e.htm

Wu, L., \& Norman, I. J. (2006). An investigation of job satisfaction, organizational commitment and role conflict and ambiguity in a sample of Chinese undergraduate nursing students. Nurse Education Today, 26(4), 304-314. http://dx.doi.org/10.1016/j.nedt.2005.10.011

Yang, S. B., \& Choi, S. O. (2009). Employee empowerment and team performance. Team Performance $M a-$ nagement: An International Journal, 15(5/6), 289301. http://dx.doi.org/10.1108/13527590910983549

Yeh, Y.-P. (2014). Exploring the impacts of employee advocacy on job satisfaction and organizational commitment: Case of Taiwanese airlines. Journal of Air Transport Management, 36(0), 94-100. http://dx.doi.org/10.1016/j.jairtraman.2014.01.002

Yen, C.-H., \& Teng, H.-Y. (2013). The effect of centralization on organizational citizenship behavior and deviant workplace behavior in the hospitality industry. Tourism Management, 36(0), 401-410. http://dx.doi.org/10.1016/j.tourman.2012.10.003

Yi, L., Uddin, M. A., Das, A. K., Mahmood, M., \& Sohel, S. M. (2019). Do Transformational Leaders Engage Employees in Sustainable Innovative Work Behaviour? Perspective from a Developing Country. Sustainability, 11(9), 2485. https://doi.org/10.3390/su11092485

Yılmaz, S. M., Çelebi, Ç. D., \& Çakmak, E. (2014). Job Satisfaction Level of Academicians in Faculty of Education. Procedia - Social and Behavioral Sciences, 116(0), 1021-1025. http://dx.doi.org/10.1016/j.sbspro.2014.01.339

Yousef, D. A. (2017). Organizational Commitment, Job Satisfaction and Attitudes toward Organizational Change: A Study in the Local Government. International Journal of Public Administration, 40(1), 77-88. http://dx.doi.org/10.1080/01900692.2015.1072217 Yucel, I., \& Bektas, C. (2012). Job Satisfaction, Organizational Commitment and Demographic Characteristics Among Teachers in Turkey: Younger is Better? Pro- 
cedia - Social and Behavioral Sciences, 46, 15981608. http://dx.doi.org/10.1016/j.sbspro.2012.05.346 Zhang, Y., \& Cun, X. (2012). Public service motivation and job satisfaction, organizational citizenship behavior. Chinese Management Studies, 6(2), 330340. http://dx.doi.org/10.1108/17506141211236758

A. K. M. Tafzal Haque, Professor of Management (University of Chittagong, Bangladesh 4331), is a distinguished academician in the field of management science. Mr. Haque is currently serving Premier University, Chattogram as Treasurer. He has published numerous research papers in local and international journals and conference proceedings on topics relating to Management, Strategic Management, and Human Resource Management.

Md. Aftab Uddin, Ph.D., is an Associate Professor of Human Resource Management in the University of Chittagong, Chattogram, Bangladesh 4331. He has more than 50 publications in national and international peer-reviewed journals and conference proceedings on leadership, intelligence, creativity and innovation, corporate greenization, education, gender, etc.
Rubina Easmin is an Assistant Professor at School of Business in East Delta University, Chattogram, Bangladesh who completed her BBA and MBA from the Department of Management, University of Chittagong, Bangladesh. She specializes at Corporate Social Responsibility, Work-life Balances, Citizenship Behavior, and Job Performance.

Shanewaz Mahmood Sohel is an Associate Professor in the Department of Human Resource Management, University of Chittagong, Chattogram, Bangladesh 4331. He has more than 15 research papers and conference proceeding in the field of human resource management, strategic management, and organizational behavior. His research areas are Human Resource Issues and Workplace Motivation. 


\section{Appendix: Survey Measures for the Study}

\begin{tabular}{|l|l|c|}
\hline Sources & Measurement items & Loadings \\
\hline \multirow{4}{*}{$\begin{array}{l}\text { (Quinn \& Mangi- } \\
\text { one, 1973) }\end{array}$} & All in all, I am satisfied with my job & 0.750 \\
\cline { 2 - 3 } & If a good friend was interested in working in a job like mine, I would recommend that job & 0.841 \\
\cline { 2 - 3 } & $\begin{array}{l}\text { Knowing what I know now about my job, if I had to do it over again, I would still have } \\
\text { pursued that job }\end{array}$ & 0.752 \\
\cline { 2 - 3 } & $\begin{array}{l}\text { In general, I would say that my job measured up to the sort of job I have wanted when I } \\
\text { took it }\end{array}$ & 0.837 \\
\hline \multirow{4}{*}{$\begin{array}{l}\text { Citizenship } \\
\text { behavior }\end{array}$} & & 0.841 \\
\hline \multirow{5}{*}{ Ritz et al. (2014) } & I adapt my time schedule to help other co-workers & 0.886 \\
\cline { 2 - 3 } & I try hard to help others so they can become integrated into my organization & 0.883 \\
\cline { 2 - 3 } & I read and keep up actively with developments of my organization & 0.857 \\
\cline { 2 - 3 } & I make innovative suggestions on how to improve the functioning of my organization & 0.796 \\
\hline \multirow{3}{*}{$\begin{array}{l}\text { Organizational } \\
\text { commitment }\end{array}$} & I am willing to put forth great effort to help the organization succeed & 0.802 \\
\cline { 2 - 3 } $\begin{array}{l}\text { Yang and Choi } \\
\text { 2009) }\end{array}$ & I talk to my friends that this organization is a great place to work & 0.744 \\
\cline { 2 - 3 } & I accept almost any type of job assignment to stay with the company & 0.817 \\
\cline { 2 - 3 } & My values and the organization's values are very similar & 0.755 \\
\cline { 2 - 3 } & I am proud to tell others that I am part of this organization & 0.789 \\
\cline { 2 - 3 } & My organization inspires me to perform at high levels & 0.712 \\
\cline { 2 - 3 } & I am very glad that I chose this organization over others during my joining & 0.807 \\
\cline { 2 - 3 } & I really care about the fate of this organization & 0.736 \\
\cline { 2 - 3 } & For me, this is the best of all possible organizations for which to work & 0.795 \\
\hline
\end{tabular}

